\title{
CORRESPONDENCE.
}

\section{RAISED BEACHES IN GOWER.}

SIR,-I have read with great interest Dr. George's recent paper on the raised beaches and associated deposits in Gower, South Wales (Proceedings Geologists' Association, 43, pt. 4, 291-324), and one of the more important results of his work is the confirmation of the fact that there is more than one raised beach in that district, with which point $I$ am in entire agreement.

There appears, however, to be considerable confusion as to the distinguishing features of his various stages, the descriptions of which are vague and misleading. For instance, although the fauna he reports from his Patella Beach and from the Neritoides Beach is that of the present shore, he calls the one cold and the other warm (p. 317). Again, the fauna which he lists on p. 297 is almost, if not quite, an ecological impossibility: if it is considered to have lived near the snouts of the valley glaciers described on p. 297, therefore the erratics found in the beach have been derived from glaciers which existed before the formation of this beach.

His confusion about my $30 \mathrm{ft}$. beach of southern England is quite needless. This raised beach, which can be seen at many places along the south coast, can be defined as showing a positive movement of about 30 feet, as containing a fauna slightly colder than that of the present day, and from the stratigraphical point of view, being interglacial in the sense that it is earlier than at least part of the head, but contains derived erratics. Contemporaneous with this beach are shingle banks up to about 50 feet at some places, as at Portland, in the Isle of Wight, and in Sussex, and it has been traced by Professor Palmer and Colonel Cooke into river gravels containing implements of approximately Mousterian date. In face of this definition this beach cannot be correlated with any preglacial beach.

If, therefore, Dr. George insists that his Patella Beach is preglacial, then it is certainly not contemporaneous with the $30 \mathrm{ft}$. beach of southern England; but it seems far more likely that the main 25 to $30 \mathrm{ft}$. beach in Gower, whose height I have measured at several points, is contemporaneous with the $30 \mathrm{ft}$. beach of southern England: we then arrive back at our original contention that Dr. George's Patella Beach is in no sense pre-glacial. In the unfortunate absence of a critical fauna in Gower, it is not possible to suggest a very definite correlation of either the Patella or the Neritoides Beach with the $30 \mathrm{ft}$. beach of southern England, but as these two beaches described by Dr. George appear to be very close in height, it must be a matter of extreme difficulty to distinguish them, at least on the open coast away from the caves.

OxFords.

D. Baden Powell.

16th January, 1933. 